\title{
Growth Stimulation by Coexpression of Transforming Growth Factor- $\alpha$ and Epidermal Growth Factor-Receptor in Normal and Adenomatous Human Colon Epithelium
}

\author{
Sanford D. Markowitz, Kay Molkentin, Catherine Gerbic, Julie Jackson, Thomas Stellato, * and James K. V. Willson \\ Ireland Cancer Center, Case Western Reserve University, and Departments of Medicine and *Surgery, \\ University Hospitals of Cleveland, Cleveland, Ohio 44106
}

\begin{abstract}
Autocrine stimulation of the epidermal growth factor receptor (EGF-R), by coexpression of transforming growth factor- $\alpha$ (TGF- $\alpha$ ), causes malignant transformation of some fibroblast cell lines. TGF- $\alpha$ and EGF-R are both known to be expressed in colon carcinoma tissue and have been shown coexpressed in colon carcinoma cell lines. TGF- $\alpha$ autocrine activation of EGF-R has been suggested as a potential mechanism contributing to abnormal growth control in colon cancer. We now report coexpression of TGF- $\alpha$ and EGF-R transcripts in morphologically normal colonic epithelium from five individuals, in colonic adenomas from three individuals, and in a nontumorigenic colon adenoma cell line, VACO-330. Functional studies demonstrate VACO-330 growth is stimulated by exogenous TGF- $\alpha$ and is completely abolished by a blocking anti-EGF-R antibody. Autocrine stimulation of EGF-R by TGF- $\alpha$ is therefore required for growth of the adenoma cell line. Autocrine stimulation of EGF-R by TGF- $\alpha$ does not cause malignant transformation of the colonic epithelial cell. In normal and adenomatous human colon TGF- $\alpha$, via either an autocrine or paracrine mechanism, is likely an important physiologic stimulant of epithelial proliferation. (J. Clin. Invest. 1990. 86:356362.) Key words: colon • autocrine • transforming growth factors
\end{abstract}

\section{Introduction}

Transforming growth factor- $\alpha$ (TGF- $\alpha)^{1}$ is a secreted polypeptide that binds to the epidermal growth factor receptor (EGFR) to produce a mitogenic stimulus (1). TGF- $\alpha$ production was initially detected in multiple transformed cell lines and in many naturally occurring human tumors (1-3). In many of these examples, the epidermal growth factor receptor was coexpressed along with TGF- $\alpha$, leading to the suggestion that

Address reprint requests to Dr. Markowitz, UCRC\#2, Suite 200, Case Western Reserve University, 11001 Cedar Road, Cleveland, OH 44106.

Received for publication 29 November 1989 and in revised form 9 April 1990.

1. Abbreviations used in this paper: EGF, epidermal growth factor; EGF-R, EGF receptor; TGF- $\alpha$, transforming growth factor- $\alpha$.

J. Clin. Invest.

(C) The American Society for Clinical Investigation, Inc.

0021-9738/90/07/0356/07 \$2.00

Volume 86, July 1990, 356-362 autocrine stimulation of the EGF-R by TGF- $\alpha$ could be one mechanism for tumors to escape normal growth controls (2-4). Indeed, using transfection to achieve coexpression of TGF- $\alpha$ and EGF-R results in transformation of several immortalized rodent fibroblast cell lines $(5,6)$. More recently TGF- $\alpha$ production has been demonstrated in skin, in activated macrophages, and in cultured normal breast epithelium (7-9). In nontransformed cultured normal breast epithelium the expressed TGF- $\alpha$ has been additionally shown to function as an autocrine growth factor that activates the coexpressed EGF-R (9). These observations suggest that autocrine growth stimulation by TGF- $\alpha$ need not be transforming, that TGF- $\alpha$ is expressed in nontransformed human tissues, and that paracrine or autocrine stimulation by TGF- $\alpha$ may be a physiologic stimulus to proliferation of some normal human tissues.

This study addresses the role of TGF- $\alpha$ in human colon epithelia. The human colonic epithelium is a rapidly proliferating organ that completely renews itself on a weekly basis (10). Neoplasia of the normal colonic epithelium proceeds through ordered stages first to adenomatous then to malignant change (11). EGF-R and TGF- $\alpha$ production have been previously individually detected in colon carcinomas and in numerous colon cancer cell lines (12-18). Coexpression of TGF- $\alpha$ and EGF-R and growth stimulation by TGF- $\alpha$ has been demonstrated in multiple colon cancer cell lines $(16,18)$, and TGF- $\alpha$ has been proposed as an autocrine growth factor in colon cancer (18). One of two recent investigations has now detected expression of TGF- $\alpha$ in normal colon $(17,19)$. In this study we provide evidence that TGF- $\alpha$ functions as a paracrine or autocrine growth factor in both adenomatous and nonneoplastic normal colon epithelium.

We have first investigated growth control of VACO-330, a nontransformed cell line established from a human colon adenoma (20). We find that VACO-330 expresses both TGF- $\alpha$ and EGF-R. VACO-330 growth can be accelerated by exogenous TGF- $\alpha$ and completely blocked by antibody against the EGF-R binding domain. In this cell culture model of adenomatous colon epithelium we thus establish growth depends on TGF- $\alpha$ autocrine stimulation. These investigations have been additionally extended to tissue samples obtained from nonmalignant human colon epithelium. In these samples coexpression of TGF- $\alpha$ and EGF-R transcripts in morphologically normal mucosa from five individuals and in adenoma tissue from three individuals was detected. We conclude that autocrine stimulation of EGF-R by TGF- $\alpha$ is characteristic of and required for growth of the adenoma cell line. Such autocrine stimulation is not itself transforming in colonic epithe- 
lium, rather, we conclude that TGF- $\alpha$ is likely important in stimulating proliferation, either by paracrine or autocrine mechanisms, in both normal and adenomatous colon epithelium. TGF- $\alpha$ antagonists may therefore be potentially useful pharmacologic agents in the treatment of colonic polyposis or other colonic diseases marked by disordered epithelial proliferation.

\section{Methods}

Cell lines. The VACO 330 cell line was maintained as described on rat tail collagen-coated plates in MEM supplemented with $2 \%$ fetal bovine serum, insulin, thyroxine, transferrin, selenium, and hydrocortisone (MEM2+ media) (20).

Tissue procurement. Adenomas were obtained from colectomy specimens and divided into sections for histopathologic analyses and RNA extraction using our previously described methods (21). Morphologically normal colonic epithelium was obtained from colectomy specimens by blunt dissection of the mucosa off the muscularis mucosae as previously described (21).

Nucleic acids. RNA was prepared from tissue and from the VACO-330 cell line by extraction with guanidine isothiocyanate as previously described (21-23). Total RNA was obtained by ultracentrifugation of the extract through a cesium cushion. Total RNA was resolved by electrophoresis on agarose-formaldehyde gels and judged to be undegraded based on the relative ethidium staining of $28 \mathrm{~S}$ and $18 \mathrm{~S}$ subunits $(22,23)$. Polyadenylated mRNA was selected by chromatography on oligo-dT cellulose $(22,23)$.

Northern analyses. $2 \mu \mathrm{g}$ of polyadenylated mRNA was resolved by electrophoresis on agarose-formaldehyde gels (23). RNA was transferred to Nytran nylon membranes (Schleicher and Schuell, Keene, $\mathrm{NH}$ ) according to the manufacturer's instructions. Double-stranded cDNA probes were labeled with ${ }^{32} \mathrm{P}$ by the random primer technique (24). Hybridization of probe to filters was at $42^{\circ} \mathrm{C}$ in $50 \%$ formamide, $5 \times$ SSPE, $2 \times$ Denhardt's solution, $0.1 \%$ SDS, $0.1 \mathrm{mg} / \mathrm{ml} \mathrm{salmon}$ sperm DNA. Final washes were in $0.1 \times \mathrm{SSC}, 0.1 \% \mathrm{SDS}, 65^{\circ} \mathrm{C}$. Blots were exposed on Kodak XAR film with an intensifying screen.

Probes. The human EGF-R probe, carried in plasmid pH 64.1, is a $1.89 \mathrm{~kb}$ Eco RI fragment of the EGF-R cDNA encoding the amino terminal portion of the molecule into the intracellular domain (25). The human TGF- $\alpha$ probe, carried in plasmid phTGF1-10-925, is a 925-bp complete cDNA (8). The human EGF probe, carried on plasmid hEGF15-1, is a complete 1.9-kb cDNA (26). The glyceraldehyde3-phosphate dehydrogenase probe is a Pst I fragment of a chicken muscle (27). Blots hybridized to GAPDH underwent final washing at $56^{\circ} \mathrm{C}$.

Growth curves. VACO 330 were plated on fresh collagen coated plates in MEM supplemented with hormones but without fetal bovine serum (MEM+ media). Cells were plated in 24 well plates at either 10,000 cells per well (low density) or 100,000 cells per well (high density). At $24 \mathrm{~h}$ additions of either, MEM+, EGF (Sigma Chemical Co., St. Louis, MO) or TGF- $\alpha$ (Gibco Laboratories, Grand Island, NY) were made. At defined time points total cell number was established by removing the cells from the plates with EDTA and counting in a hemacytometer.

Antibody studies. Anti-EGF-R monoclonals, Ab528 and Ab455 $(28,29)$, were purchased from Oncogene Science, Inc. (Manhasset, NY). Cells were plated in MEM+ media in 24 well plates at 100,000 cells per well (high density) and growth curves in the presence of antibody or antibody plus EGF performed as above.

\section{Results}

Coexpression of TGF- $\alpha$ and EGF-R by an adenoma cell line. We initially characterized VACO-330, a human cell line established from a small colonic tubular adenoma. VACO-330 exhibits typical epithelial features including tight junctions, apical brush boarder and basal nuclei (20). It neither clones in soft agarose nor forms tumors in nude mice (20). It has near diploid karyotype with the addition of a single chromosome 7 . VACO-330 thus provides a cell culture model of the nontransformed colon adenoma cell.

Fig. 1 demonstrates by northern analyses coexpression of both TGF- $\alpha$ and EGF-R transcripts in the VACO-330 cell line. Expression of both TGF- $\alpha$ and EGF-R transcripts is greater in the VACO-330 colon adenoma cell line than in the colon carcinoma cell line, SW480, previously demonstrated to coexpress these products (16). EGF-R expression in VACO-330 is clearly less than in line A431, in which the EGF-R gene is amplified, but far exceeds the SW620 line, in which EGF-R has previously been shown undetectable (16, 30). Southern analyses of VACO-330 genomic DNA showed no evidence of EGF- $R$ gene amplification, but confirmed a $50 \%$ increase in EGF-R gene copy number, consistent with VACO-330's known trisomy 7 (data not shown).

Autocrine activation of VACO-330 EGF-R. We next addressed whether EGF-R transcript expression in VACO-330 results in expression of a functional receptor with growth promoting activity. Fig. $2 \mathrm{~A}$ shows supplementation of serum free VACO-330 growth medium with TGF- $\alpha$ or EGF (epidermal growth factor) increases VACO-330 growth four- to fivefold compared with unsupplemented controls. Both TGF- $\alpha$ and EGF attain maximal activity at $10 \mathrm{ng} / \mathrm{ml}$. Stimulation of VACO-330 growth by either TGF- $\alpha$ or EGF was repeatedly demonstrated when VACO-330 were plated at 10,000 cell per 16-mm well (low density). However, exogenous TGF- $\alpha$ and EGF had no effect on growth of VACO-330 plated at 10-fold higher density of 100,000 cells/well (high density) (Fig. 2 B). This finding suggested that at high cell concentration endogenous TGF- $\alpha$ production might be sufficient to fully stimulate VACO-330 growth.

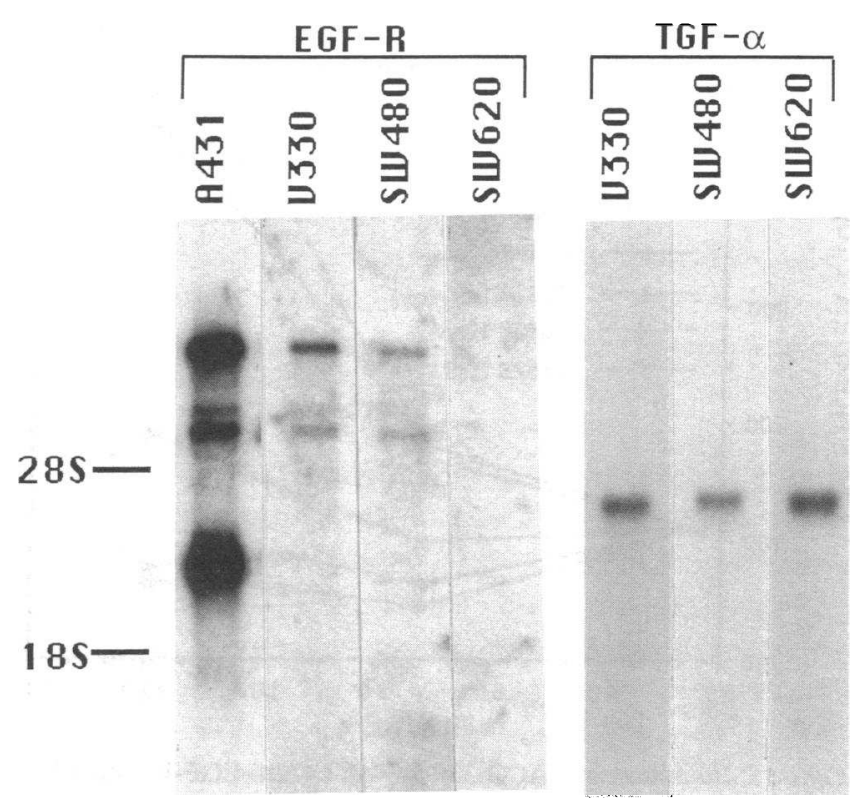

Figure 1. EGF-R and TGF- $\alpha$ coexpression in a colon adenoma cell line. RNA blot hybridization of polyadenylated RNA $(2 \mu \mathrm{g})$ extracted from colon adenoma cell line VACO-330 (V330), colon cancer cell lines SW480 and SW620, and reference cell line A431. Blots were hybridized with TGF- $\alpha$ (40) or EGF-R (8) cDNA probes. 

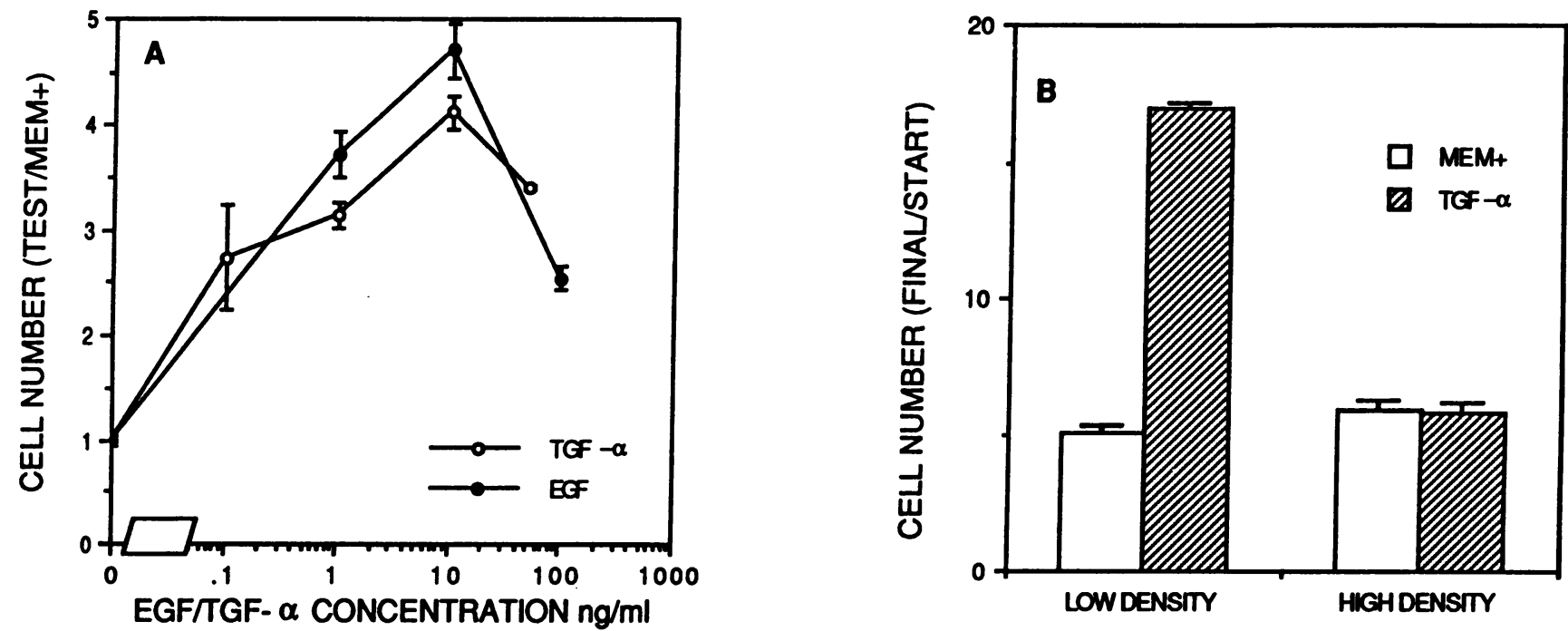

Figure 2. Stimulation of VACO-330 growth by EGF and TGF- $\alpha$. $(A)$ VACO-330 cells were maintained as previously described in MEM media supplemented with hormones (insulin, thyroxine, hydrocortisone, and transferrin) and $2 \%$ fetal calf serum (25). Cells were replated at time 0 in MEM+ (MEM supplemented with hormones but without serum) at 10,000 cells per 16-mm well (low density). EGF or TGF- $\alpha$ was added at 24 hours and cell counts determined at $120 \mathrm{~h}$. Shown is final cell number in growth factor-treated wells divided by the final cell number in control MEM+ only wells. $(B)$ Cells were plated at 10,000 per well (low density) or at 100,000 per well (high density) in MEM+. At $24 \mathrm{~h}$ half the wells received $10 \mathrm{nM}$ TGF- $\alpha$. Shown are cell numbers attained at $120 \mathrm{~h}$, divided by the initially plated cell number. In $A$ and $B$ mean values and standard errors are derived from triplicate experiments.

The dependence of growth of high density VACO-330 on endogenous TGF- $\alpha$ was tested by using antibodies to block the EGF-R ligand binding site. Ab528 is known to block ligand binding to and activation of the EGF-R without stimulating either receptor phosphorylation or cell division $(28,29)$. Ab455, directed against the carbohydrate moiety of the EGF-R, blocks neither ligand-receptor binding, ligand induced receptor phosphorylation, or ligand-induced mitogenesis $(28$,
29). Fig. $3 \mathrm{~A}$ shows addition of $10 \mathrm{~nm}$ EGF-R-blocking antibody, Ab528, totally abolishes growth of high density VACO-330. In contrast $20 \mathrm{~nm}$ nonblocking anti-EGF-R Ab455 has no effect on VACO-330 growth. Thus, only the anti-EGF-R antibody that inhibits EGF-R function will also inhibit VACO-330 growth. Ab528 has binding constant of 2.5 $\mathrm{nM}$, and in other systems addition of exogenous EGF competes it from the EGF-R (31). To confirm Ab528 induced
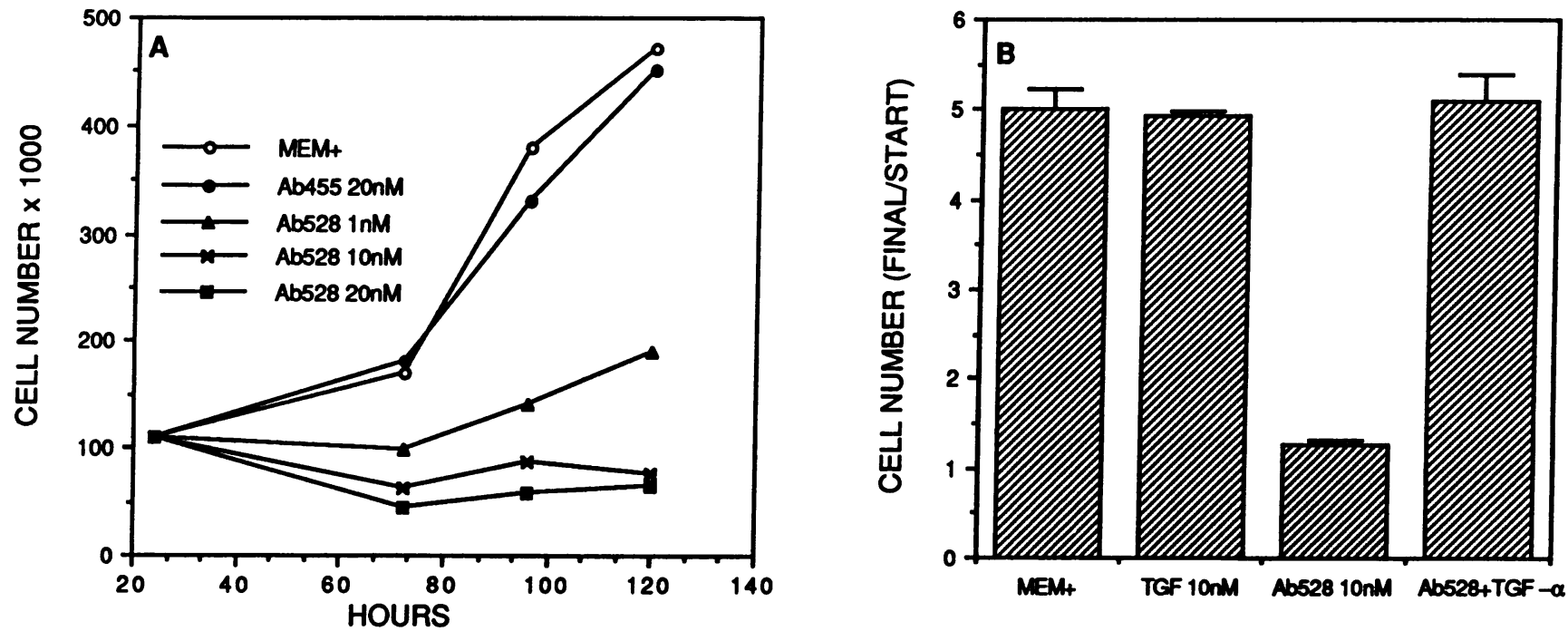

Figure 3. Inhibition of VACO-330 growth by anti-EGF-R antibodies. (A) Growth curves of antibody treated VACO-330. VACO-330 cells were plated at time 0 in serum free MEM+ at 100,000 cells per 16-mm well (high density). At $24 \mathrm{~h}$ additions were made of 1-20 nM EGF-R blocking Ab528, or $20 \mathrm{nM}$ nonblocking anti-EGF-R Ab455 $(20,28)$. Shown are daily average cell counts determined in duplicate wells followed through $120 \mathrm{~h}$ of growth. $(B)$ TGF- $\alpha$ reversal of antibody mediated growth inhibition. Cells were plated as in $A$. At $24 \mathrm{~h}$ additions were made of: MEM+ media, MEM+ with $10 \mathrm{nM}$ added TGF- $\alpha$; MEM+ with $10 \mathrm{nM}$ added Ab528; and MEM+ with both $10 \mathrm{nM}$ added Ab528 and 10 $\mathrm{nM}$ added TGF- $\alpha$. Final cell numbers were determined at $120 \mathrm{~h}$ and are shown divided by the initially plated cell number. Means and standard errors are determined from triplicate experiments. 
growth inhibition is mediated through EGF-R blockade, we used excess TGF- $\alpha$ to compete Ab528 from the VACO-330 EGF-R. Fig. $3 B$ shows that whereas addition of TGF- $\alpha$ has no effect on basal growth of high density VACO-330, addition of $10 \mathrm{nM}$ TGF- $\alpha$ to Ab528-treated VACO-330 does, as predicted, reverse the Ab528-induced inhibition of VACO-330 growth. This result confirms that Ab528 inhibits VACO-330 growth specifically by antagonizing EGF-R activation. These findings demonstrate that growth of high density VACO-330 remains dependent on a functional EGF-R, and suggest that in high density VACO-330 EGF-R stimulation is fully provided by endogenous production of TGF- $\alpha$. Thus in VACO-330 TGF- $\alpha$ is both expressed and, in an autocrine manner, stimulates VACO-330 growth.

In vivo coexpression of EGF-R and TGF- $\alpha$. We next addressed whether coexpression in VACO-330 of TGF- $\alpha$ and EGF-R transcripts has been selected for in culture or is representative of colon adenoma growth in man. RNA was obtained and extracted from three human colonic adenomas. Fig. $4 A$ shows Northern analyses demonstrating that in each of the colon adenomas TGF- $\alpha$ and EGF-R transcripts are coexpressed at levels comparable to those seen in the
VACO-330 adenoma cell line. We finally addressed whether coexpression of TGF- $\alpha$ and EGF-R occurs in morphologically normal colon epithelium or only in neoplastic adenomatous epithelium. Fig. $4 B$ shows Northern analyses demonstrating that in each of five different samples of morphologically normal colon epithelium TGF- $\alpha$ and EGF-R transcripts are coexpressed at levels comparable to those seen in the VACO-330 adenoma cell line.

While expression of EGF has been previously detected in the small bowels of patients with Crohn's disease and in one reported sample of human colon $(19,32)$; Northern analyses did not in our hands detect EGF expression in any of the RNAs we prepared from normal or adenomatous colon tissue or from the VACO-330 cell line (data not shown).

\section{Discussion}

This study demonstrates that in colon epithelium autocrine growth stimulation by TGF- $\alpha$ can occur independently of malignant transformation. This study further demonstrates that in the VACO-330 colon adenoma cell lines, growth is absolutely dependent on autocrine stimulation by TGF- $\alpha$. And this study demonstrates that TGF- $\alpha$ and EGF-R are coexpressed in
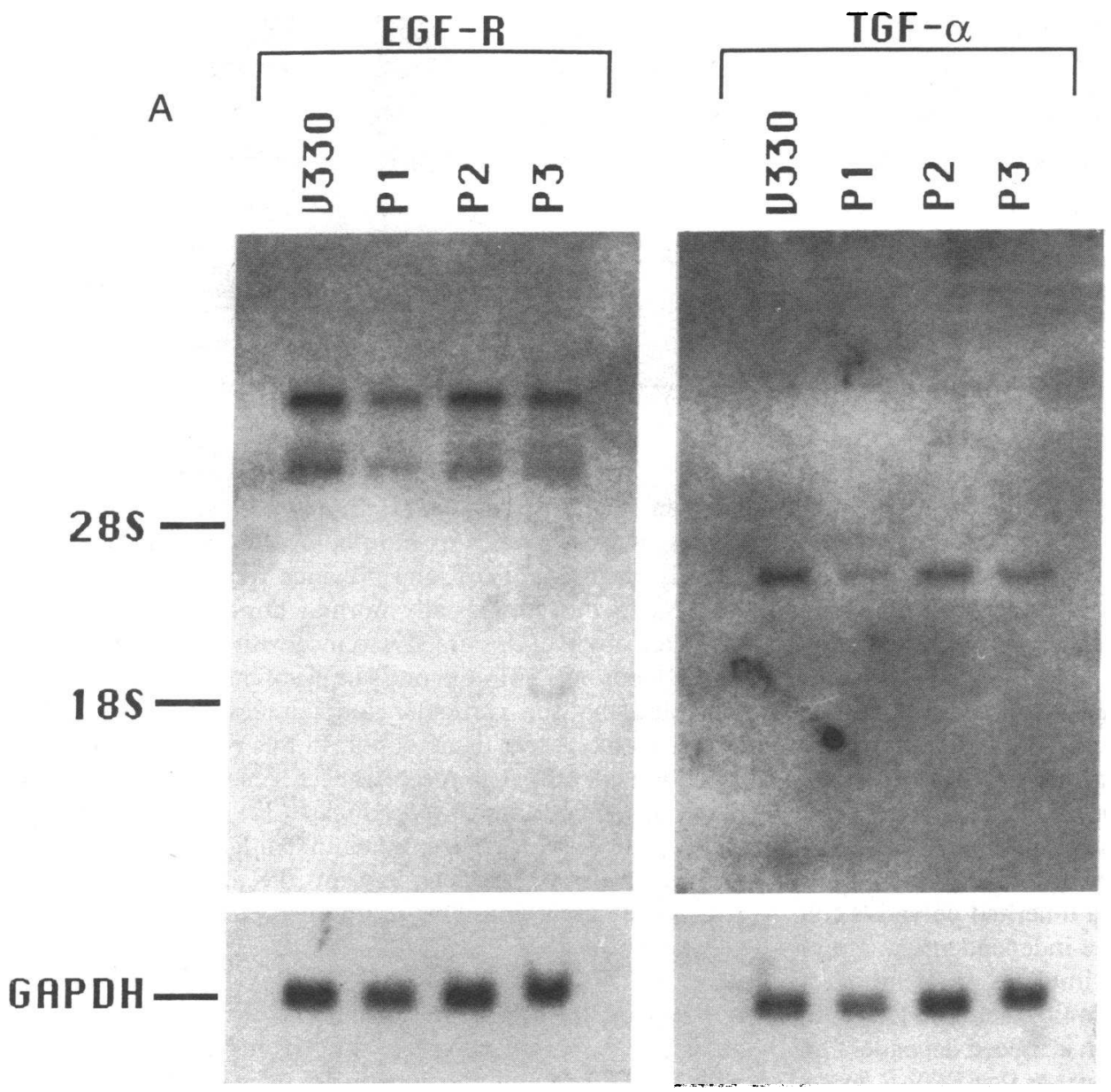

Figure 4. (A) RNA blot hybridization of polyadenylated RNA extracted from adenomas of three patients, P1-3, compared with $2 \mu \mathrm{g}$ of VACO-330 polyadenylated RNA. Duplicate blots were first hybridized with TGF- $\alpha$ or EGF-R probes, then rehybridized with a glyceraldehyde3-phosphate dehydrogenase (GAPDH) cDNA probe (29). (B) RNA blot hybridization of polyadenylated RNA extracted from morphologically normal colon epithelium of five patients, N1-5, compared with $2 \mu \mathrm{g}$ of VACO-330 polyadenylated RNA. Duplicate samples were first hybridized with TGF- $\alpha$ or EGF-R probes, then rehybridized with a glyceraldehyde-3-phosphate dehydrogenase (GAPDH) cDNA probe (27). Underlined samples were present together on the same nylon blot and are therefore directly comparable. 


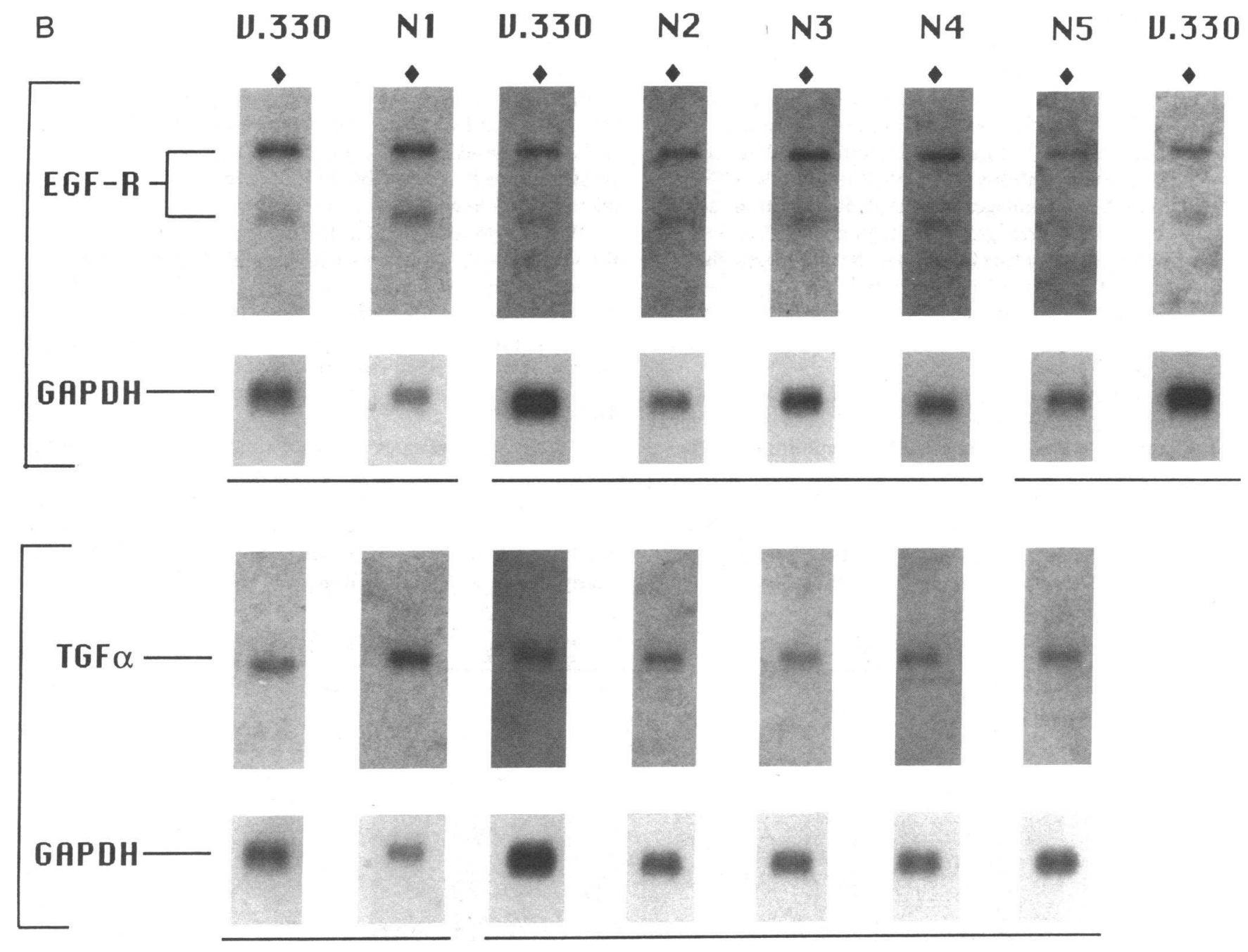

man both in morphologically normal and in adenomatous colonic epithelium. Together these observations suggest that TGF- $\alpha$ is likely in man an important stimulant of proliferation of normal and adenomatous colonic epithelium and that TGF- $\alpha$ stimulation in vivo may work by either paracrine or autocrine mechanisms.

We find that in the VACO-330 adenoma cell line TGF- $\alpha$ growth stimulation is through an autocrine mechanism. We cannot distinguish whether in adenoma tissue TGF- $\alpha$ and EGF-R are expressed on the same or on different cells. However, our hypothesis that in adenoma tissue TGF- $\alpha$ is an important growth factor is consistent with previous observations that (a) adenomas from patients with inherited polyposis coli produce factors supporting anchorage-independent growth of Rat-1 cells (33), and (b) that EGF stimulates proliferation of primary cultures established from colonic adenomas (34). Our findings that adenoma cell line growth is indeed dependent on autocrine activation of the EGF-R suggests that EGF-R antagonists may have potential clinical utility in the treatment or prevention of colonic adenoma in high risk individuals.

Our detection of EGF-R in morphologically normal human colon epithelium is consistent with previous observations demonstrating that in vivo intravenous EGF is a potent mitogen for rat colonic epithelium (35). Our detection of TGF- $\alpha$ in five samples of morphologically normal colon is strongly confirmatory of one previous report of TGF- $\alpha$ expression in morphologically normal human colon mucosa (17). Our observations are at variance with one report detecting EGF but not TGF- $\alpha$ in one sample of human colon (19). It is possible that this particular sample reflected circumstances unique to the parent tissue donor. In this regard we note that induction of EGF has recently been reported in the small bowel of patients with Crohn's disease (32). Our study of morphologically normal colon epithelium contains a potential bias in that our tissue donors underwent colectomy due to coexistent colon carcinoma. Our morphologically normal mucosa was taken from the distal portion of the resection specimens, which were in all cases histologically free of disease and were well separated from the tumor mass. However, other investigators have demonstrated that the flat mucosa of individuals with colon carcinoma is in general hyperproliferative compared with that from normal individuals (36). While it may therefore be premature to extend our observations to the population at large, our data certainly suggest that TGF- $\alpha$ is likely an important colonic mitogen which in vivo acts to stimulate proliferation of the colonic epithelium. Our data support the 
possibility that TGF- $\alpha$ antagonists may be useful pharmacologic agents in conditions marked by increase proliferation of colon epithelium.

This study adds to previous investigations that have established the utility of anti-EGF-R monoclonal antibodies, and particularly of Ab528, as useful reagents for demonstrating the biologic function of the activated EGF-R $(9,28,29,31,37)$. Treatment of VACO-330 with Ab528 reveals an absolute dependence of VACO-330 growth on EGF-R activation. In this investigation we demonstrated growth inhibition of VACO-330 is due to Ab528 blockade of the EGF-R ligand binding site first by comparison with anti-EGF-R Ab455, which binds to the EGF-R without blocking receptor ligand interactions. Secondly, we demonstrated reversal of the Ab528-induced growth inhibition when Ab528 is completed from the EGF-R. Other investigators have observed similar reversal by ligand of the growth inhibitory effects of anti-EGF$R$ antibody. However, in high density VACO-330 we demonstrate such reversal under conditions in which the ligand, exogenous TGF- $\alpha$, is in the absence of antibody without effect on cell growth. By separating the competition of Ab528 by ligand from any direct stimulatory properties of ligand, we further demonstrate that Ab528 growth inhibition depends on its causing EGF-R blockade. We anticipate future technical advances will likely allow the establishment of primary cultures of normal colonic epithelium. When such cultures become available, use of Ab528 will allow direct testing of our suggestion that growth of morphologically normal colonic epithelium is dependent on TGF- $\alpha$ stimulation.

This study adds to the emerging picture that TGF- $\alpha$ autocrine stimulátion is not necessarily a transforming event, that occurrence in nature of TGF- $\alpha$ autocrine stimulation is not restricted to cancers, and that TGF- $\alpha$ autocrine stimulation may be a physiologic mechanism employed to increase proliferation of nontransformed epithelium. Previous investigations have shown that autocrine stimulation of the EGF-R, achieved by transfection of either TGF- $\alpha$ or EGF into the rodent Rat-1 and FR3T3 fibroblast cell lines, causes malignant transformation of those lines and confers on them the capacity for tumorigenic growth in nude mice $(5,31)$. Numerous previous studies have suggested a possible role for TGF- $\alpha$ as an autocrine growth factor in solid tumors in general and colon cancer in particular $(2,12-17,38)$. However, this study demonstrates that in an immortalized colonic epithelial cell line, VACO-330, TGF- $\alpha$ autocrine stimulation of EGF-R is not transforming and induces neither anchorage independent growth in soft agar nor tumorigenic growth in the nude mouse. Our observations are consistent with the recent demonstration that TGF- $\alpha$ is an autocrine growth factor in nontransformed cultured normal breast epithelium (9). We concur with the authors of that study in the suggestion that normal and malignant epithelia may differ not in the existence of autocrine growth stimulation but in the response to such stimulation (9). Recent investigations have defined a series of mutations associated with the progression of colon neoplasia to colon cancer $(9,39)$. An important future application of the VACO-330 cell line will be as a nontransformed target for the introduction of these mutations. As our current observations show, such future experiments will allow direct determination of the ability of activated oncogenes to alter cellular responses to TGF- $\alpha$ autocrine stimulation.

\section{Acknowledgments}

We thank Dr. Axel Ullrich for providing an EGF-R cDNA and Dr. Graeme Bell for providing TGF- $\alpha$ and EGF cDNAs. We thank the tissue procurement service of the CWRU Cancer Research Center for obtaining human colon tissue samples. We thank Dr. H. J. Kung for encouragement and for helpful scientific discussion.

This work supported by U.S. Public Health Service grant P30CA43703, awarded to Case Western Reserve University Cancer Research Center, U.S. Public Health Service grant U01-CA4596701, awarded to Dr. Wilson, and by grant to Dr. Markowitz from Ohio Division, Cuyahoga chapter, American Cancer Society.

\section{References}

1. Derynck, R. 1988. Transforming growth factor $\alpha$. Cell. 54:593595.

2. Derynck, R., D. Goeddel, A. Ullrich, J. Gutterman, R. Williams, T. Bringman, and W. Berger. 1987. Synthesis of messenger RNAs for transforming growth factors $\alpha$ and $\beta$ and the epidermal growth factor receptor by human tumors. Cancer Res. 47:707-712.

3. De Larco, J., and G. Todaro. 1978. Growth factors from murine sarcoma virus-transformed cells. Proc. Natl. Acad. Sci. USA. 75:40014005.

4. Sporn, M., and G. Todaro. 1980. Autocrine secretion and malignant transformation cells. New Engl. J. Med. 303:878-880.

5. Rosenthal, A., P. Lindquist, T. Bringman, D. Goeddel, and R. Derynck. 1986. Expression in rat fibroblasts of a human transforming growth factor- $\alpha$ cDNA results in transformation. Cell. 46:301-309.

6. Di Marco, E., J. Pierce, T. Fleming, M. Kraus, C. Molloy, S. Aaronson, and P. Di Fiore. 1989. Autocrine interaction between TGF- $\alpha$ and the EGF-receptor: quantitative requirements for induction of the malignant phenotype. Oncogene. 4:831-838.

7. Coffey, R., R., Derynck, J. Wilcox, T. Bringman, A. Goustin, H. Moses, and M. Pittelkow. 1987. Production and auto-induction of transforming growth factor- $\alpha$ in human keritoncytes. Nature (Lond.). 328:817-820.

8. Madtkes, D., E. Raines, K. Sakariassen, R. Assoian, M. Sporin, G. Bell, and R. Ross. 1988. Induction of transforming growth factor- $\alpha$ in activated human alveolar macrophages. Cell. 53:285-293.

9. Bates, S., E. Valverius, B. Ennis, D. Bronzert, J. Sheridan, M. Stampfer, J. Mendelsohn, M. Lippman, and R. Dickson. 1990. Expression of the transforming growth factor- $\alpha /$ epidermal growth factor receptor pathway in normal human breast epithelial cells. Endocrinology. 126:596-607.

10. Friedman, E. 1989. A primary culture system of human colon carcinoma cells and its use in evaluating differentiation therapy. In Cell and Molecular Biology of Colon Cancer. L. Augenlicht, editor. CRC Press, Boca Raton, FL 69-85.

11. DeVita, V., S. Hellman, and S. Rosenberg. 1985. Principles and Practice of Oncology. J. B. Lippincott, Philadelphia.

12. Coffey, R., G. Shipley, and H. Moses. 1986. Production of transforming growth factors by human colon cancer lines. Cancer Res. 46:1164-1169.

13. Anzano, M., D. Rieman, W. Prichett, D. Bowen-Pope, and R. Greig. 1989. Growth factor production by human colon carcinoma cell lines. Cancer Res. 49:2898-2904.

14. Watkins, L., M. Brattain, and A. Levine. 1988. Modulation of a high molecular weight form of transforming growth factor- $\alpha$ in human colon carcinoma cell lines. Cancer Lett. 40:59-70.

15. Bradley, S., G. Garfinkle, E. Walker, R. Salem, L. Chen, and G. Steele. 1986. Increased expression of the epidermal growth factor receptor on human colon carcinoma cells. Arch. Surg. 121:1242-1247.

16. Coffey, R., A. Goustin, A. Soderquiat, G. Shipley, J. Wolfshohl, G. Carpenter, and H. Moses. 1987. Transforming growth factor $\alpha$ and $\beta$ expression in human colon cancer lines: implication for an autocrine model. Cancer Res. 47:4590-4594. 
17. Malden, L., U. Novak, and A. Burgess. 1989. Expression of transforming growth factor alpha messenger RNA in the normal and neoplastic gastro-intestinal tract. Int. J. Cancer. 43:380-384.

18. Mulder, K., and M. Brattain. 1989. Growth factor expression and response in human colon carcinoma cells. In Cell and Molecular Biology of Colon Cancer. L. Augenlicht, editor. CRC Press, Boca Raton, FL. 45-67.

19. Finch, P., J. Rubin, M. Toru, D. Ron, and S. Aaronson. 1989. Human KGF is FGF-related with properties of a paracrine effector of epithelial cell growth. Science (Wash. DC). 245:752-755.

20. Wilson, J., G. Bittner, T. Oberley, G. Meisner, and J. Weese. 1987. Cell culture of human colon adenomas and carcinomas. Cancer Res. 47:2704-2713.

21. Markowitz, S., T. Stellato, M. Haut, C. Gerbic, and K. Molkentin. 1989. Expression of the ErbA-B class of thyroid hormone receptors is selectively lost in human colon carcinoma. J. Clin. Invest. 84:1683-1687.

22. Davis, L., M. Dibner, and J. Battey. 1986. Basic Methods in Molecular Biology. Elsevier Science Publishers, New York.

23. Markowitz, S., G. Krystal, A. Lebacq-Verheyden, J. Way, E. Sausville, and J. Battey. 1988. Transcriptional activation and DNase I hypersensitive sites are associated with selective expression of the gastrin-releasing peptide gene. J. Clin. Invest. 82:808-815.

24. Feinberg, A., and B. Vogelstein. 1983. A technique for radiolabeling DNA restriction fragments to high specific activity. Anal. Biochem. 132:6-13.

25. Ullrich, A., L. Coussens, J. Hayflick, T. Dull, A. Gray, A. Tam, J. Lee, Y. Yarden, T. Libermann, J. Schlessinger, J. Downward, E. Mayes, N. Whittle, M. Waterfield, and P. Seeburg. 1984. Human epidermal growth factor receptor cDNA sequence and aberrant expression of the amplified gene in A431 epidermoid carcinoma cells. Nature (Lond.). 309:418-425.

26. Bell, G., N. Fong, M. Stempien, M. Wormsted, D. Caput, K. Lailing, M. Urdea, L. Rall, and R. Aamches-Pescadoar. 1986. Human epidermal growth factor precursor: cDNA sequence, expression in vitro and gene organization. Nucleic Acids Res. 14:8427-8446.

27. Dugaiczyk, A., J. Haron, E. Stone, O. Dennison, K. Rothblum, and R. Schwartz. 1983. Cloning and sequencing of a deoxyribonucleic acid copy of glyceraldehyde-3-phosphate dehydrogenase messenger ribonucleic acid isolated from chicken muscle. Biochemistry. 22:16051613.

28. Sato, J., T. Kawamoto, A. Le, J. Mendelsohn, J. Polikoff, and G. Sato. 1983. Biological effects in vitro of monoclonal antibodies to human epidermal growth factor receptor. Mol. Biol. Med. 1:511-529.
29. Gill, G., T. Kawamoto, C. Cochet, A. Le, J. Sato, H. Masui, C. McLeod, and J. Mendelsohn. 1984. Monoclonal anti-epidermal growth factor receptor antibodies which are inhibitors of epidermal growth factor binding and antagonists of epidermal growth factorstimulated tyrosine protein kinase activity. J. Biol. Chem. 259:77557760.

30. Carpenter, G. 1987. Receptors for epidermal growth factor and other polypeptide mitogens. Annu. Rev. Biochem. 56:881-914.

31. Kawamoto, T., J. Sato, A. Le, J. Polikoff, G. Sato, and J. Mendelsohn. 1983. Growth stimulation of A431 cells by epidermal growth factor: Identification of high-affinity receptors for epidermal growth factor by an anti-receptor monoclonal antibody. Proc. Natl. Acad. Sci. USA. 80:1337-1341.

32. Wright, N., C. Pike, and G. Elia. 1990. Induction of a novel epidermal growth factor-secreting cell lineage by mucosal ulceration in human gastrointestinal stem cells. Nature (Lond.). 343:82-85.

33. Wigley, C., C. Paraskeva, and R. Coventry. 1986. Elevated production of growth factor by human premalignant colon adenomas and a derived epithelial cell lines. Br. J. Cancer. 54:799-805.

34. Friedman, E., P. Higgins, M. Lipkin, H. Sinya, and A. Gelb. 1981. Tissue culture of human epithelial cells from benign colonic tumors. In Vitro. 17:632-644.

35. Goodlad, R., T. Wilson, W. Lenton, H. Gregory, K. McCullagh, and N. Wright. 1987. Intravenous but not intragastric urogastrone-EGF is trophic to the intesting of parenterally fed rats. Gut. 28:573-582.

36. Lipkin, M. 1989. Intermediate biomarkers of increased susceptibility to cancers of the large intestine. In Cell and Molecular Biology of colon cancer. L. Augenlicht, editor. CRC Press, Boca Raton, FL. 97-109.

37. Arteaga, C., E. Coronado, and C. K. Osborne. 1988. Blockade of the epidermal growth factor receptor inhibits transforming growth factor $\alpha$-induced but not estrogen induced growth or hormone-dependent human breast cancer. Mol. Endocrinol. 2:1064-1069.

38. Stern, D., D. Hare, M. Cecchini, and R. Weinberg. 1987. Construction of a novel oncogene based on synthetic sequence encoding epidermal growth factor. Science (Wash. DC). 235:321-324.

39. Bos, J., E. Fearon, S. Hamilton, M. Verlaan-de Vries, J. Boom, A. Van der Eb, and B. Vogelstein. 1987. Nature (Lond.). 327:293-297.

40. Baker, S., E. Fearon, J. Nigro, S. Hamilton, A. Preisinger, J. M. Jessup, P. VanTuinen, D. Ledbetter, D. Barker, Y. Nakamura, R. White, and B. Vogelstein. 1989. Chromosome 17 deletions and p53 gene mutations in colorectal carcinomas. Science (Wash. DC). 244:217-221. 